\title{
The reasons of the implementation of the concept of smart villages in the European Union
}

\begin{abstract}
The aim of this article is to identify the main challenges facing the rural areas in the European Union (EU) and to investigate whether implementation of the concept of smart villages makes it possible to face these challenges. These challenges are: depopulation, aging of the society, climate change, growing demand for food, environmental degradation, peripheralization or low income of rural populations, pandemic COVID-19. The first part describes the situation in rural areas, using statistical data from the reports of the European Commission and Eurostat. Then the roots of the concept of smart villages in the European Union were presented. Its six components have been identified: smart society, smart economy, smart agriculture, smart management, smart environment and smart associability. In the last part, it was checked whether the implementation of the concept of smart villages responds to the main challenges faced by rural areas.
\end{abstract}

Key words: smart villages, European Union, rural areas, smart accessibility, smart environment, smart rural society

\section{Introduction}

European Community and now European Union has implemented rural development - policy since 1980s (first as an element of structural policy and later as an separate policy - rural development policy). Dynamic changes taking place in rural areas in the European Union and in global economy make the countryside new challenges. Every public intervention requires identifying challenges first and than setting the goals, instruments and tools of activities. The aim of this article is to identify the main challenges facing the rural areas in the European Union (EU) and to investigate whether implementation of the concept of smart village makes it possible to face these challenges. The research hypothesis is as follows: the concept of smart villages addresses the main challenges facing rural areas in the EU. The answers for these questions: What are the main challenges facing rural areas in the EU? What elements does the concept of smart villages contain? Will the implementation of the concept of smart villages allow to meet the indicated challenges? allow to verify this hypothesis. The research goal required the use of qualitative research method, therefore desk research was used.

\section{Challenges facing rural areas in the $\mathrm{EU}$}

Rural areas face many challenges. European Commission detailed a list of them in the communication: A long-term Vision for the EU's Rural Areas - Towards stronger, connected, resilient and prosperous rural areas by 2040 (European Commission, 2021). 
These are: ageing of rural population, depopulation, low access to public services such as: health care, education, low attractiveness rural areas as a place to live and work, lower Gross Domestic Product (GDP), share of population at the risk of poverty and social exclusion, gender employment gap, lower digital skills and access to ICT, lower quality of public services and infrastructure (Ibidem, pp. 4-6; European Commission, 2019, pp. 15-21). There are also some global challenges, which have an influence on rural areas: climate changes, loss of biodiversity on a land and marine, growing world population, growing demand for food and excessive use of resources (European Commission, 2021a, p. 82). Since 2020 we need take into apart also pandemic COVID-19. All these challenges we can group. These are listed in Figure 1.

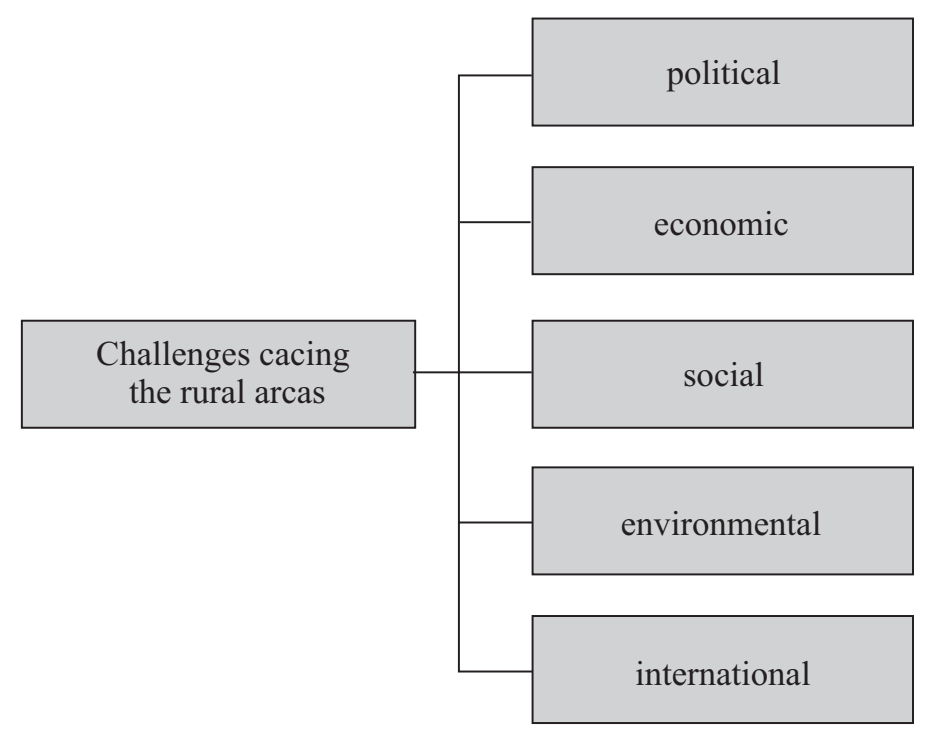

Figure 1. Challenges facing rural areas in the $\mathbf{E U}$

Source: Own preparation.

The economic conditions include the level of development measured by the size of GDP per capita, or the level of income obtained by employees of specific industries compared to the average level of income in the economy.

Under an urban-rural typology developed by the EC, there are 3 types of NUTS (Nomenclature of Territorial Units for Statistics) - level regions: predominantly urban, intermediate and predominantly rural ${ }^{1}$ (Eurostat, 2021) with urban regions having a much higher GDP per capita than the rest. GDP per capita in rural areas in 2018 was EUR 19,302, in intermediate areas EUR 24,551 and urban areas EUR 35,786 (CAP). GDP per capita in urban areas represented more than $120 \%$ of the average EU GDP per capita, compared to just over $70 \%$ in rural areas (see graph 1 ).

${ }^{1}$ The classification is based on the determination of the population density per $1 \mathrm{~km}^{2}$. Predominantly urban regions have at least $80 \%$ of the population residing in urban clusters, intermediate regions between $50 \%$ and $80 \%$ of the population in urban clusters, while rural regions have at least $50 \%$ of the population living in rural grid cells. 
Graph 1. GDP per capita by type of region in relation to the EU-28 average (in \%)
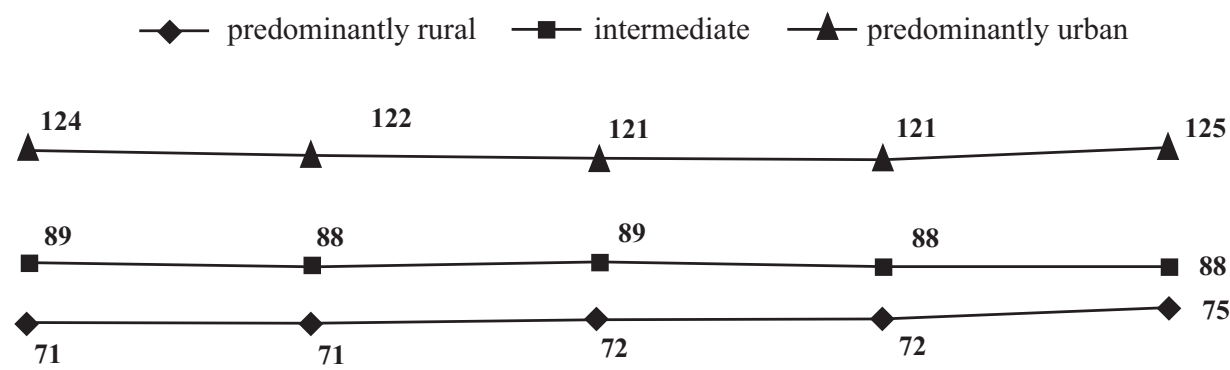

$2008 \quad 2010 \quad 2012 \quad 2014 \quad 2018$

Source: DG Agriculture and Rural Development, 2018, p. 4; European Commission, 2021b.

In the EU, the percentage of people employed in agriculture is increasingly diminishing (in 2016 it was 12.7\%). However, it is still an important source of income for many families, especially those living in rural regions. Since 2005, we have seen an increase in the incomes of people working in agriculture compared to those of people working in other sectors (except 2007-2009, the global financial crisis). In 2019, the average level of agricultural incomes was just $45 \%$ of the average wage in the economy, much lower than workers in the industrial and service sectors. In addition, in 2018, the purchasing power standad ${ }^{2}$ (PPS) in the EU-28 was on average 30,158 PPS. Predominantly urban regions had incomes about 5,000 PPS higher than the average at 35,275 PPS. In predominantly rural regions, the income was estimated at a much lower level of 20,067 PPS, while in the intermediate regions it was 24,735 PPS (Ibidem).

Graph 2. Farmers' income compared with the wages in the rest of economy

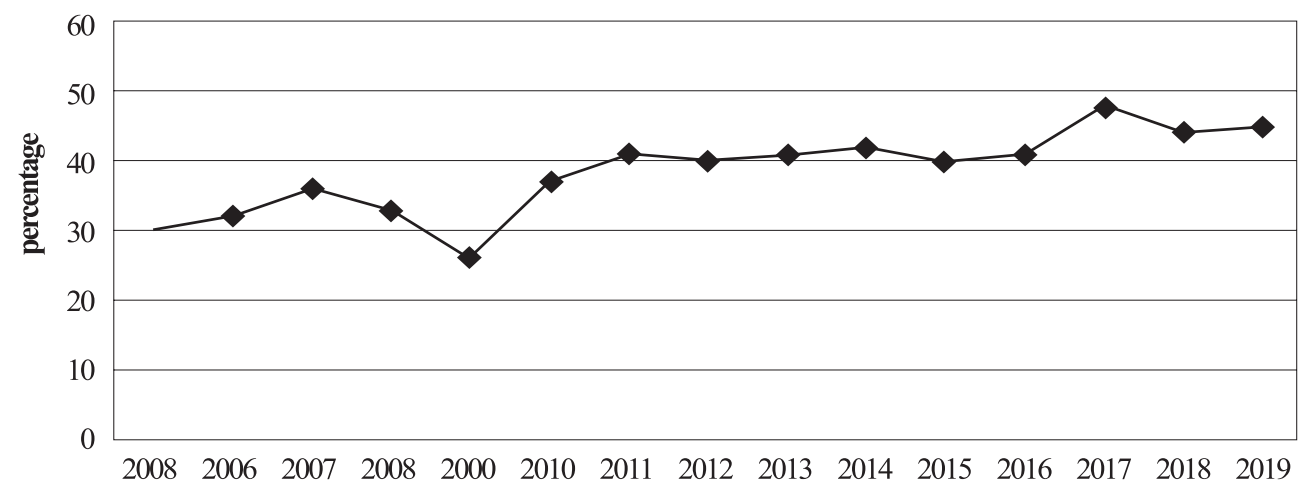

Source: Jobs, 2021.

${ }^{2}$ An indicator developed by Eurostat. It is assumed that the same number of goods and services can be purchased for 1 PPS in each Member State. 
The social challenges facing rural areas are: depopulation, aging, population at the risk of poverty and social exclusion, access to digital technology and public services. Almost a third of the population is still living in rural areas. The data presented in the table 1. and table 2 . illustrate selected problems faced by rural communities, which then translate into the amount of economic development needed in these regions. One of the most pressing problems of rural areas is their depopulation. This process is happening unevenly across the EU. Greece, Poland and Slovakia are the only Member States where, between 2006 and 2016, there has been an increase in the relative share of the rural population. On average, it fell by around $0.9 \%$ in the EU-28, most notably in Estonia (2.5\%), Romania (1.9\%), Austria (1.7\%) and Finland (1.6\%) (DG Agriculture and Rural Development, 2018, pp. 8-10). The UN estimates that by 2050, the population of rural regions in Europe will have fallen by 73 million (from 190 million in 2018 to 117 million in 2050), while urban populations will have grown by 46 million (from 553 million in 2018 to 599 million in 2050) (Raugaze, 2017). ${ }^{3}$

Between 2011 and 2016, the population of rural regions in the EU decreased by 1.3\%, compared to a $0.7 \%$ increase in intermediate regions and a $2.7 \%$ increase in urban regions. In rural regions, the decrease occurred in the group of people who are of pre-working age, i.e. below 15 (by 3.4\%) and working-age (15-64 years of age, by 3.8\%), while the number of those in post-working age (above 64) increased by 9.5\% (Koessl, 2018) (see Table 2.). The ageing of the rural population is another problem. In 2018, more than $1 / 5$ of the rural population was over 65 years old. On the other hand, it should be stressed that between 2015 and 2018 there was a slight increase in the proportion of the population living in rural regions compared to the total population (from $28 \%$ in 2015 to $29.1 \%$ in 2018).

The rural population in the EU has a lower level of education. Less than $29 \%$ of the rural population between the ages of 30 and 34 have a university degree, compared to $50 \%$ of the urban population. Young people in the countryside tend to leave education earlier than their urban counterparts. This translates into a greater risk of poverty and social exclusion both of which are more prevalent in rural areas. A lack of access to broadband Internet and digital skills are important elements which deepen this exclusion. Less than half the population of rural areas have basic digital skills, compared to $62 \%$ in cities. Unemployment rate is higher in the cities, but the differences between the employment rate for woman and men is higher in rural areas (woman $-67 \%$ and men $-80 \%$ ) and in cities (woman - 68\% and men - 78\%) (European Commission, 2021b).

Table 1

Situation in cities, towns and suburbs and rural areas in 2018 (in \%)

\begin{tabular}{|l|c|c|c||}
\hline \multicolumn{1}{|c|}{ Specification } & Cities & Towns and suburbs & Rural areas \\
\hline Share of population & 39.3 & 31.6 & 29.1 \\
\hline People aged 30-34 with tertiary education & 50.0 & 33.5 & 28.4 \\
\hline Early leavers from education and training & 9.6 & 11.4 & 11.1 \\
\hline Unemployment rate & 8.1 & 7.1 & 6.3 \\
\hline People at risk of poverty and social exclusion & 21.5 & 19.9 & 23.7 \\
\hline People considering their health good or very good & 70.3 & 69.2 & 65.6 \\
\hline People with basic or above basic digital skills & 62.0 & 55.0 & 48.0 \\
\hline
\end{tabular}

Source: Eurostat, 2020.

${ }^{3}$ The data are European-wide. 
Age structure (\% of total)

\begin{tabular}{|l|c|c|c||}
\hline \multicolumn{1}{|c|}{ Specification } & Rural regions & Intermediate regions & Urban regions \\
\hline \% of all population & 20.8 & 38.9 & 40.2 \\
\hline Less than 15 years & 15.2 & 15.1 & 15.4 \\
\hline From 15 to 64 years & 63.8 & 64.5 & 65.6 \\
\hline 65 years or over & 21.0 & 20.3 & 19.0 \\
\hline
\end{tabular}

Source: DG Agriculture and Rural Development, 2018.

The political conditions for implementing the SV concept in the European Union include long-term objectives and directions for development. The European Green Deal is a strategy prepared by the European Commission in 2016, which assumes ambitious objectives in the area of climate and environmental protection and requires profound transformation in the area of economy and society. The priorities (as in the Europe 2020 strategy) include three areas: social (fair, prosperous society), economic (modern, resource-efficient and highly competitive economy) and environmental (economic growth will not be linked to the use of natural resources, and greenhouse gas emissions will reach a net of zero in 2050) (European Commission, 2019). The environmental component is central to the strategy, underpinning the social and economic objectives. Placing greater importance on renewable energy sources and construction and renovation investments will not only contribute to improving energy efficiency and the use of more environmentally friendly energy production technologies but at the same time to reducing energy poverty and creating new jobs (the EC estimates this will create 600,000 new jobs). A circular economy using innovative, clean technologies and intelligent mobility is not only supposed to reduce the consumption of natural resources and produce less waste but also to protect the life and health of citizens and make the EU's industrial production competitive on world markets. It should ensure that the Union's food system guarantees safe and healthy food, produced in an environmentally friendly manner and that the price of these products reflects the resources used and is affordable for consumers. An important environmental objective, linked to social and economic objectives, is to protect and restore biodiversity and ecosystems (Ibidem, p. 4). The EC also draws attention to the participatory aspect - citizens should be involved in the social dialogue on the aforementioned issues and the education system should discuss issues relating to the need to achieve the objectives of the European Green Deal (Ibidem, pp. 22-23). The implementation of these elements is not possible without increased expenditure on the R\&D sector and the implementation of innovative solutions in many sectors: energy, food, transport, industry and education to name but a few.

On 5-6 September 2016, a conference organized by the European Commission on the future of rural development was held in Cork, Ireland. It resulted in the Cork 2.0 Declaration, a renewed version of the 1996 Declaration. It indicated that agricultural and rural development policy should be "innovative, integrated and inclusive" (ENDR, 2016 , p. 4). The participants of the conference set three groups of objectives within the framework of the indicated policies: economic, environmental and social, the implementation of which is aimed at improving the welfare and quality of life for rural European residents. The economic objectives relate to the use of innovative technologies, strength- 
ening local production networks, increasing the competitiveness of the agri-food sector, also by using the ICT networks. Social objectives are linked to economic objectives. Obtaining competitive advantages is not possible without investment in research and development and human capital (knowledge transfer is to take place through training or consultancy). Investment in public services and infrastructure is also crucial. The environmental objectives include preserving the natural heritage of rural areas, providing environmental public goods and the proper management of natural resources (soil, water, flora and fauna). The contribution of rural areas to climate protection is to be an important element of the measures taken to combat climate change (Ibidem, pp. 4-7).

Next group of challenges are environmental reasons such as: the green houses gases emission, loss of biodiversity and environmental pollution.

The landscape of Europe is probably the most fragmented in the world and most of its land has been used by humans. Approximately less than $20 \%$ of Europe's land we can classify as wild areas (Temple, Cox, 2009, p. 1). That has significant consequences for biodiversity. Many species (especially living in western Europe) are under pressure of human activity: agriculture and intensification of food production, timber production, waste production, infrastructure development and urban sprawl. Economic activity causes water pollution, desertification, acidification and eutrophication (European Environmental Agency, 2007, p. 8), air pollution, soil erosion and climate changes. All these phenomena have impact on biodiversity.

International Union for Conservation of Nature (IUCN) estimated, that 1,677 species among 15,060 assessed in Europe is threatened (Parlament Europejski, 2020). The worst situation is in the case of freshwater molluscs, to which we include bivalves and gastropods (see table 3 ). For example there are $100 \%$ threatened species among margaritiferidae family and 50\% among dreissenidae (included in bivalves), $75 \%$ acroloxidae, $50.3 \%$ hydrobiidae and 50\% amnicolidae (included in gastropods) are threatened species (Cuttelod, Seddon, Neubert, 2011). Also European endemic trees are highly endangered. In total, there are 252 endemic species trees, 64 of them (25\%) are critically endangered, 53 are endangered and 30 are vulnerable (Rivers, Beech, 2019, p. 9).

Table 3

Species threatened in Europe (in \%)

\begin{tabular}{|l|c|c|c|c||}
\hline \hline Name of species & Freshwater molluses & $\begin{array}{c}\text { European's endemic } \\
\text { trees }\end{array}$ & Freshwater fish & Amphibians \\
\hline \% of threatened & 59.0 & 58.0 & 40.0 & 23.0 \\
\hline Name of species & Reptiles & Mammals & Dragonflies & Wild crops \\
\hline \% of threatened & 20.0 & 17.0 & 16.0 & 16.0 \\
\hline Name of species & Birds & Butterflies & Bees & $\begin{array}{c}\text { Terrestrial } \\
\text { molluses }\end{array}$ \\
\hline \% of threatened & 13.0 & 9.0 & 9.0 & 22.0 \\
\hline Name of species & Saproxylic beetles & Aquatic plants & Marine fish & Medicinal plants \\
\hline$\%$ of threatened & 15.0 & 8.0 & 8.0 & 8.0 \\
\hline
\end{tabular}

Source: IUCN, 2015.

Agriculture produces about $9.56 \%$ of total green houses gases (GHGs) emission (Eurostat, 2015). In 2018 this sector in the EU-28 emitted 435.3 million metric tons GHGs 
(Statista, 2021). In agriculture there are 5 ways of emission: enteric fermentation $(4.32 \%$ of total GHGs emission), agricultural soil (3.67\%), manure management (1.48\%), field burning of agricultural residues and others $(0.06 \%)$ and rice cultivation $(0.06 \%)$ (Eurostat, 2015).

International challenges facing rural areas are connected with the commitment to achieving the Sustainable Development Goals (SDGs) set by United Nations and Paris Agreement's goals.

The Sustainable Development Goals (SDGs) were established by the United Nations in 2015. The implementation of 17 SDGs is possible thanks to actions such as poverty reduction, elimination of hunger, combating climate change, providing access to clean water and sanitation, ensuring access to environmentally friendly energy, eliminating inequalities, improving health and quality of life, the use of innovative solutions in industry, and responsible production and consumption. The failure to meet basic needs as articulated in the objectives set by the United Nations is particularly characteristic of developing countries (United Nations, 2015a).

There are about 190 Parties of Paris Agreement, which was approved in December 2015 during Paris climate conference. The European Union formally ratified it on 5 October 2016. The main goal of the agreement is to holding the increase in the global average temperature to well below $2^{\circ} \mathrm{C}$ above pre-industrial levels. All parties aim to limit the temperature increase to $1.5^{\circ} \mathrm{C}$ above pre-industrial levels. Achieving this goal would reduce the risks and impacts of climate changes (United Nations, 2015).

\section{The concept of Smart Villages in the EU}

The implementation of an EU strategy entitled Europe 2020: a strategy for smart, sustainable and inclusive growth required many initiatives. Therefore, the European Commission (EC) has set up the European Network for Rural Development (ENRD), aimed at reaching the widest possible range of stakeholders involved in rural development (European Network for Rural Development, 2021). In 2017, the Smart and Competetive Rural Area Team created a special committee which worked on the Smart Villages initiative from September 2017 to July 2020. During the initial stages of the project, the group focused on how digital and social innovations could contribute to the revitalization of villages and raise the living standards of their inhabitants in various domains such as transport, education, health, and environment. In the second phase, the group prepared recommendations on how to use existing tools to support the development of smart villages in the EU (European Network for Rural Development, 2021a). The group also participated in the EU Action for Smart Villages initiative, as presented in a document published by the EC on the $11^{\text {th }}$ of April 2017. This contains a vision of rural development and initiatives within the framework of rural development policy, regional policy, transport, research, digital technologies and funds that will support the construction of Smart Villages (European Commission, 2017). It includes a definition of a Smart Villages (SV) and areas of intervention that support the implementation of this concept. The idea "refers to rural areas and communities which build on their existing strengths and assets as well as on developing new opportuni- 
ties" (Ibidem, p. 3). The idea is to use the latest knowledge, information and communication technologies and innovation to improve living conditions in Europe's rural areas. The introduced measures are to cover all aspects of socio-economic life in rural areas, including employment, healthcare, access to education, access to communication and broadband Internet, public services and civic participation. These innovations and technologies are to fulfill two functions: to improve the standard and quality of life of the rural population and to be environmentally friendly (Ibidem). This is to be stimulated on a grassroots level and local specialities are to become the driving force of individual regions.

Next accepted document, which promotes the concept of the smart villege was Bled Declaration (Smart, 2018). Franc Bogovic and Tibor Szanyi highlighted, that the aims of the Smart Villages initiative is to: "create a rural areas where people can and want to life, because innovation, digital solutions make their lives easy and comfortable" (Ibidem, p. 1). This document presents examples of actions, which will realize the assumption of this concept such as: building digital platforms: e-administration, e-learning, social innovation, bio based economy, rural tourism etc.) (Zavratnik, Kos, Stojmenova, 2018, p. 6).

The European Network for Rural Development defines the concept of smart villages as: "Smart Villages are communities in rural areas that use innovative solutions to improve their resilience, building on local strengths and opportunities. They rely on a participatory approach to develop and implement their strategy to improve their economic, social and/or environmental conditions, in particular by mobilizing solutions offered by digital technologies" (European Network for Rural Development, 2019, p. 1).

The analysis of these definitions allows to indicate some components of the concept of smart villages. These are:

1) Smart society - high level of participation, using ICT, increasing level of education, creating social innovation, reduction of poverty and social exclusion, protecting rural tradition and culture;

2) Smart economy - increase the level of income in the countryside, more better job places, creating new workplaces outside agriculture, using new technologies friendly for environment, creating innovation, circular economy;

3) Smart environment - reduction of GHG emission, reduction of pollution, protection of biodiversity, environment, implementation of the principle of sustainable development, protecting rural landscape;

4) Smart governance - inclusion different stakeholder in decision making process (public authority, social partners, economic partners, NGOs), creating long term vision of developing rural areas based on endogenous factors;

5) Smart agriculture - using new technologies in agriculture, increasing the meaning of ICT in the process of production and management of farm, using environmental friendly technology, reduction of pollution of agricultural production;

6) Smart accessibility - building facilities for rural population (access to public services, such as: education, health care, access to ICT, high quality of public infrastructures (roads, bridges, rail), transport connection, access to culture (libraries, theater, cinemas). 


\section{Smart villages as an answer for challenges facing rural areas}

It is needed to check if implementation of the concept of smart villages is an answer for challenge, which were identified above. Therefore the challenges will be compared with the assumption of the results of implementation this concept.

Table 4

Key element of smart villages

\begin{tabular}{|c|c|c|}
\hline Challenges & $\begin{array}{c}\text { Implementation } \\
\text { of the component of } S V\end{array}$ & Results \\
\hline $\begin{array}{l}\text { depopulation low attractiveness } \\
\text { rural areas as a place to live and } \\
\text { work higher than in the city share } \\
\text { of population at the risk of pover- } \\
\text { ty and social exclusion low digital } \\
\text { skills }\end{array}$ & Smart society & $\begin{array}{l}\text { using ICT increasing level of ed- } \\
\text { ucation creating social innovation } \\
\text { reduction of poverty and social ex- } \\
\text { clusion protecting rural tradition and } \\
\text { culture }\end{array}$ \\
\hline $\begin{array}{l}\text { low GDP per capita gender employ- } \\
\text { ment gap less innovation }\end{array}$ & Smart economy & $\begin{array}{l}\text { increase the level of income in the } \\
\text { countryside, more better job places, } \\
\text { creating new workplaces outside } \\
\text { agriculture, using new technologies } \\
\text { friendly for environment creating } \\
\text { innovation }\end{array}$ \\
\hline $\begin{array}{l}\text { climate changes loss of biodiversity } \\
\text { on a land and marine excessive use } \\
\text { of resources }\end{array}$ & Smart environment & $\begin{array}{l}\text { zero emission-economy reduction of } \\
\text { pollution protection of biodiversity } \\
\text { implementation of the principle of } \\
\text { sustainable development }\end{array}$ \\
\hline $\begin{array}{l}\text { growing world population growing } \\
\text { demand for food climate changes } \\
\text { pollution }\end{array}$ & Smart agriculture & $\begin{array}{l}\text { new technologies in agriculture in- } \\
\text { creasing the meaning of ICT in the } \\
\text { process of production and manage- } \\
\text { ment of farm using environmental } \\
\text { friendly technology reduction of } \\
\text { pollution of agricultural production }\end{array}$ \\
\hline low level of public participation & Smart governance & $\begin{array}{l}\text { Networks between public authority } \\
\text { and socio-economic partners }\end{array}$ \\
\hline $\begin{array}{l}\text { low access to public services such } \\
\text { as: health care, education low access } \\
\text { to ICT low quality of infrastructure } \\
\text { low access to culture low transport } \\
\text { connection }\end{array}$ & Smart accessibility & $\begin{array}{l}\text { better access to public services such } \\
\text { as: education, health care, better ac- } \\
\text { cess to ICT, high standard of public } \\
\text { infrastructures access to cultural in- } \\
\text { stitution transport connection }\end{array}$ \\
\hline
\end{tabular}

Source: Own preparation.

The analysis shows, that indicated challenges facing rural areas in the European Union can be meet, if the concept of smart villages will be implemented. We need to remember that, these are only assumptions, which need adequate instruments and tools. Member States and European Commission are working on this.

There is a key element of this new approach. Effective implementation of the concept of smart village require using of multi-level governance and involvement of wild range of local stakeholders. 


\section{Conclusion}

1. The following challenges facing rural areas in the EU countries has been identified: depopulation, aging of the society, climate change, growing demand for food, environmental degradation, peripheralization or low income of rural populations, pandemic COVID-19. New threatens involves new approach to the rural development policy. Since the second decade of twenty century European Union has started to promote new concept of rural development - smart villages. There are not one definition of this concept, but we can indicate some common elements such as building facilities for rural population, using ICT technology, environmental protection and building zero-emission economy, limitation of poverty and exclusion, improvement of the quality of life on rural areas and involvement of local stakeholder in the process of management this area.

2. Six components of the concept of smart villages have been identified: smart society, smart economy, smart agriculture, smart governance, smart environment and smart associability.

3. The analysis demonstrated that this new concept of rural development can be useful for meeting the challenges facing rural areas. The hypothesis put forward becomes affirmed. Next step is to build set of instruments, which will implement its assumption.

4. Process of building set of instruments require involvement of local rural communities (which is a key part of this approach) and creating individual path of development based on endogenous factors.

5. Analysis of effectiveness of instruments proposed by European Commission is a task for further research.

\section{Bibliography}

CAP contest indicators - 2019 update, https://ec.europa.eu/info/sites/info/files/food-farming-fisheries/ farming/documents/cap-context-indicators-table_2019_en.pdf, 10.09.2021.

Cuttelod A., Seddon M., Neubert E. (2011), European Red List of Non-marine Molluscs, Publications Office of the European Union, Luxembourg.

ENDR (2016), Cork 2.0 Declaration: A Better Life for Rural Areas, https://enrd.ec.europa.eu/sites/ default/files/cork-declaration_en.pdf, 20.09.2021.

DG Agriculture and Rural Development (2018), Rural area and the primary sector in the EU, https:// ec.europa.eu/info/sites/info/files/food-farming-fisheries/farming/documents/eu-rural-areas-primary-sector_en.pdf, 12.09.2021.

European Commission (2019), Communication form the Commission: The European Green Deal, Brussels, COM(2019) 640 final.

European Commission (2021), Communication form the Commission to the European Parliament, the Council, the Economic and Social Committee and the Committee of the Regions: A long-term Vision for the EU's Rural Areas - Towards stronger, connected, resilient and prosperous rural areas by 2040, Brussels, COM(2021) 345 final.

European Commission (2021a), Commission Staff Working Document, Accompanying the document: Communication form the Commission to the European Parliament, the Council, the Economic and Social Committee and the Committee of the Regions: A long-term Vision for the EU'S Rural Areas - Towards stronger, connected, resilient and prosperous rural areas by 2040, $\operatorname{SWD}(2021) 166$ final, Part 2/3. 
European Commission (2021b), EU rural area in numbers, https://ec.europa.eu/info/strategy/priorities-2019-2024/new-push-european-democracy/long-term-vision-rural-areas/eu-rural-areas-numbers_en, 12.09.2021.

European Commission (2017), EU Action for Smart Villages.

European Commission (2019), Pilot Project: Smart and eco-social villages, Final Report, Brussels.

European Environmental Agency (2007), Halting the loss of biodiversity by 2010: proposal for a first set of indicators to monitor progress in Europe, Technical Report, no. 11/2007.

European Network for Rural Development (2021), About the ENRD, https://enrd.ec.europe.eu/about_ en, 13.10.2021.

European Network for Rural Development (2021a), ENRD Thematic Work, https://enrd.ec.europa.eu/ enrd-thematic-work_en\#2, 13.10.2021.

European Network for Rural Development (2019), Smart Villages. Pilot Project, Brussels, https:// digitevent-images.s3.amazonaws.com/5c0e6198801d2065233ff996-registrationfiletexteditor-1551115459927-smart-villages-briefing-note.pdf, 14.10.2021.

Eurostat (2015), Archive: Agri-environmental indicator - greenhouse gas emissions, https:/ec.europa.eu/eurostat/statistics-explained/index.php?title=Archive:Agri-environmental_indicator_-_ greenhouse_gas_emissions\&oldid $=374989,13.10 .2021$.

Eurostat (2020), Urban and rural living in the EU, https://ec.europa.eu/eurostat/web/products-eurostat-news/-/EDN-20200207-1, 16.09.2021.

Eurostat (2021), Urban-rural typology, https://ec.europa.eu/eurostat/statistics-explained/index.php?title=Archive:Urban-rural_typology, 10.09.2021.

IUCN (2015), European Species under Threat, Overview of European Red List Results, https://www. iucn.org/downloads/red_list_overview_new_1.pdf, 20.09.2021.

Jobs and growth in rural areas (EU-27), https://agridata.ec.europa.eu/extensions/DashboardIndicators/ JobsGrowth.html, 13.09.2021.

Koessl G. (2018), Demographic change in Europe urban vs. rural, https://futurium.ec.europa.eu/en/ urban-agenda/housing/urban-blog/demographic-change-europe-urban-vs-rural, 14.09.2021.

Parlament Europejski (2020), Zagrożone gatunki w Europie: fakty i liczby (infografika), https://www. europarl.europa.eu/news/pl/headlines/society/20200519STO79424/zagrozone-gatunki-w-europie-fakty-i-liczby-infografika, 16.09.2021

Raugaze I. (2017), Policy brief, Shrinking rural region in Europe, https://www.espon.eu/sites/default/ files/attachments/ESPON\%20Policy\%20Brief\%20on\%20Shrinking\%20Rural\%20Regions. pdf, 13.09.2021.

Rivers M. C., Beech E., Bazos I., Bogunić F., Buira A., Caković D., Carapeto A., Carta A., Cornier B., Fenu G., Fernandes F., Fraga P., Garcia Murillo P. J., Lepší M., Matevski V., Medina F. M., Menezes de Sequeira M., Meyer N., Mikoláš V., Montagnani C., Monteiro-Henriques T., Naranjo Suárez J., Orsenigo S., Petrova A., Reyes-Betancort J. A., Rich T., Salvesen P. H., Santana López I., Scholz S., Sennikov A., Shuka L., Silva L. F., Thomas P., Troia A., Villar J. L., Allen D. J. (2019), European Red List of Trees, IUCN, Cambridge UK-Brussels, Belgium.

Smart Villiges, Bled Declaration for a Smarter Future of the Rural Area in EU (2018), https://pametne-vasi.info/wp-content/uploads/2018/04/Bled-declaration-for-a-Smarter-Future-of-theRural-Areas-in-EU.pdf, 16.10.2021.

Statista (2021), Annual greenhouse gas emissions from agriculture in the European Union (EU-28) from 2008 to 2018, https://www.statista.com/statistics/879954/annual-greenhouse-gas-emissions-from-agriculture-in-european-union/, 13.10.2021.

Temple H. J., Cox N. A. (2009), European Red List of Ambitions, Office for Official Publications of the European Communities, Luxembourg.

United Nations (2015), Paris Agreement. 
United Nations (2015a), Transforming our World: the 2030 Agenda for Sustainable Development, $\mathrm{A} / \mathrm{RES} / 70 / 1$.

Zavratnik V., Kos A., Stojmenova E. (2018), Smart Villages: Comprehensive Review of Initiatives and Practices, "Sustainability" 10/2559.

\section{Uwarunkowania wdrażania koncepcji smart villages w Unii Europejskiej}

\section{Streszczenie}

Celem niniejszego artykułu była identyfikacja głównych wyzwań stojących przed obszarami wiejskimi w Unii Europejskiej (UE) oraz zbadanie, czy realizacja koncepcji smart villages umożliwi sprostanie tym wyzwaniom. Do tych wyzwań zaliczamy: depopulację, starzenie się społeczeństwa, zmiany klimatyczne, rosnący popyt na żywność, degradacja środowiska, peryferyzacja, czy niskie dochody populacji wiejskich oraz pandemię COVID-19. W pierwszej części dokonano charakterystyki sytuacji na obszarach wiejskich, wykorzystując dane statystyczne pochodzące m.in. z raportów KE i Eurostatu. Następnie zaprezentowano korzenie koncepcji smart villages w Unii Europejskiej. Wyszczególniono sześć jej komponentów: smart society, smart economy, smart agriculture, smart management, smart environment and smart associability. W ostatniej części sprawdzono, czy wdrożenie koncepcji smart village odpowiada na główne wyzwania stojące przed obszarami wiejskimi.

Slowa kluczowe: smart villages, Unia Europejska, obszary wiejskie, smart dostępność, smart środowisko, inteligentne społeczności wiejskie 